\title{
Nitric Oxide Emission Reduction in Reheating Furnaces through Burner and Furnace Air-Staged Combustions
}

\author{
Yonmo Sung ${ }^{1, *} \mathbb{1}$, Seungtae Kim ${ }^{2}$, Byunghwa Jang ${ }^{2}$, Changyong $\mathrm{Oh}^{3}$, Taeyun Jee ${ }^{4}$, Soonil Park ${ }^{4}$, Kwansic Park ${ }^{5}$ \\ and Siyoul Chang ${ }^{5}$ \\ 1 Department of Energy and Mechanical Engineering, Gyeongsang National University, Tongyeonghaean-ro 2, \\ Tongyeong-si 53064, Korea \\ 2 Environment and Energy Engineering Team, Hyundai Steel Company, Dangjin-si 31719, Korea; \\ kstpoem@hyundai-steel.com (S.K.); bhjang@hyundai-steel.com (B.J.) \\ 3 Environment and Energy Planning Team, Hyundai Steel Company, Dangjin-si 31719, Korea; \\ cyoh1017@hyundai-steel.com \\ 4 Large Section Mill Department, Hyundai Steel Company, Incheon 22525, Korea; \\ mihas@hyundai-steel.com (T.J.); psiii62@hyundai-steel.com (S.P.) \\ 5 Environment Management Team, Hyundai Steel Company, Incheon 22525, Korea; \\ kwansic.park@hyundai-steel.com (K.P.); narci@hyundai-steel.com (S.C.) \\ * Correspondence: ysung@gnu.ac.kr; Tel.: +82-55-772-9115
}

Citation: Sung, Y.; Kim, S.; Jang, B.; Oh, C.; Jee, T.; Park, S.; Park, K.; Chang, S. Nitric Oxide Emission Reduction in Reheating Furnaces through Burner and Furnace Air-Staged Combustions. Energies 2021, 14, 1599. https://doi.org/ 10.3390/en14061599

Academic Editor: T M Indra Mahlia

Received: 24 February 2021

Accepted: 11 March 2021

Published: 13 March 2021

Publisher's Note: MDPI stays neutral with regard to jurisdictional claims in published maps and institutional affiliations.

Copyright: (c) 2021 by the authors. Licensee MDPI, Basel, Switzerland. This article is an open access article distributed under the terms and conditions of the Creative Commons Attribution (CC BY) license (https:// creativecommons.org/licenses/by/ $4.0 /)$.

\begin{abstract}
In this study, a series of experiments were conducted on a testing facility and a real-scale furnace, for analyzing the nitric oxide (NO) emission reduction. The effects of the temperature, oxygen concentration, and amount of secondary combustion air were investigated in a single-burner combustion system. Additionally, the NO-reduction rate before and after combustion modifications in both the burner and furnace air-staged combustion were evaluated for a real-scale reheating furnace. The air-to-fuel equivalence ratio $(\lambda)$ of individual combustion zones for the furnace was optimized for NO reduction without any incomplete combustion. The results indicated that the NO emission for controlling the $\lambda$ of a single-zone decreased linearly with a decrease in the $\lambda$ values in the individual firing tests (top-heat, bottom-heat, and bottom-soak zones). Moreover, the multizone control of the $\lambda$ values for individual combustion zones was optimized at 1.13 (top-preheat), 1.0 (bottom-preheat), 1.0 (top-heat), 0.97 (bottom-heat), 1.0 (top-soak), and 0.97 (bottom-soak). In this firing condition, the modifications reduced the $\mathrm{NO}$ emissions by approximately $23 \%$, as indicated by a comparison of the data obtained before and after the modifications. Thus, the combined application of burner and furnace air-staged combustions facilitated NO-emission reduction.
\end{abstract}

Keywords: reheating furnace; low- $\mathrm{NO}_{\mathrm{x}}$ burner; combustion modification; staged combustion; coke oven gas; $\mathrm{NO}_{x}$ emission

\section{Introduction}

In the iron and steel industry, improving the energy efficiency and reducing air pollutant emissions are major topics of interest. With the rapid development of the iron and steel industry, the energy consumption and the level of emissions are increasing annually [1-3]. In particular, reheating furnaces are the main energy- and emission-intensive equipment used in the hot rolling process (producing final steel products from semi-finished materials) and significantly affect the energy consumption and emitting detrimental gases such as $\mathrm{CO}_{2}, \mathrm{SO}_{2}$, and $\mathrm{NO}_{\mathrm{x}}$ [4-7]. These emissions are generated because reheating furnaces for thermal input use fossil fuels such as coke oven gas (COG) or mixed gases in the integrated steel plant based on the blast furnace and natural gas (NG) or liquefied petroleum gas (LPG) in the mini steel plant based on the electric arc furnace [8,9]. Moreover, there has been tremendous pressure on the iron and steel industry to restrict pollutant emissions; in particular, $\mathrm{NO}_{\mathrm{x}}$ emissions from steel-production plants must be controlled to satisfy strin- 
gent regulations. This is a worldwide issue because the production of steel is constantly increased by China and other developing countries [10].

In the Seoul metropolitan area (SMA), which includes Seoul metropolitan city, Incheon metropolitan city, and Gyeonggi-do, South Korea, the Korean government implemented special measures in the 1990s to improve the air quality [11]. Nevertheless, because the level of air pollutants in the SMA is 1.7-3.5 times higher than those in other mega cities (New York, London, and Osaka etc.) in the world, the "Special Act on the Improvement of Air Quality in SMA" was enacted in 2003 and enforced in 2005 [12,13]. Additionally, to reduce and manage the emissions from industrial facilities, a project to support the installation of low $\mathrm{NO}_{x}$ burners was introduced, and the cap-and-trade system (CATS) for the air pollutants in the SMA was started in 2007 [11]. The CATS for the air pollutants in the SMA allocates yearly emission allowances for $\mathrm{NO}_{\mathrm{x}}$ and $\mathrm{SO}_{\mathrm{x}}$ to large facilities, requiring them to keep their emissions within the allowances and trade any surplus allocations [14]. In the Incheon works of Hyundai Steel Company (HSC), South Korea, the annual allowance for $\mathrm{NO}_{\mathrm{x}}$ emissions is 348 tons/year by 2017, and the emissions must be reduced to 195 tons/year by 2022. The $\mathrm{NO}_{\mathrm{x}}$ emissions from the four reheating furnaces at the Incheon works account for $90 \%$ of the total emissions. For these reasons, research on $\mathrm{NO}_{\mathrm{x}}$-emission reduction in reheating furnaces was initiated into the combustion modification through the burner and furnace air-staged combustion presented herein.

To satisfy the above $\mathrm{NO}_{\mathrm{x}}$ emission limits, technologies such as primary methods (airstaged combustion, reburning, flue gas recirculation, the use of low- $\mathrm{NO}_{x}$ burners, etc.) and secondary methods (selective catalytic reduction, selective non-catalytic reduction, steam injection, etc.) have been widely used for combustion-related applications [15-20]. Among the existing methods, air-staged combustion is one of the most efficient and attractive technologies for reducing $\mathrm{NO}_{\mathrm{x}}$ emissions, because of its low installation and operation costs. Hence, this study focuses on combustion modifications using burner and furnace air staged combustions for $\mathrm{NO}_{\mathrm{x}}$-emission reduction in reheating furnaces, without any additional investment.

Studies involving a single-burner test and testing facilities (but not tests in real-scale reheating furnaces) are described as follows. Teng [21] investigated the effect of air-staged combustion in burners on $\mathrm{NO}_{x}$ emission reduction and achieved an approximately $60 \%$ reduction by controlling the combustion air injection ratios between primary and secondary proportions. Jaafar et al. [16] investigated air-staged combustion for $\mathrm{NO}_{\mathrm{x}}$ reduction in an oil burner system and reported a reduction of 30\% in the case of air staging compared to with the case without air staging. Cheong et al. [22] investigated for different values of thermal input, injection diameter, and global equivalence ratio in a propane-air premixed combustion system. They concluded that the effects of the temperature, equivalence ratio, recirculation rate, and residence time should be systematically considered when optimizing the combustion furnace for NO-emission reduction. Lukáč et al. [17] and Zajemska et al. [20] performed combustion experiments for $\mathrm{NO}_{\mathrm{x}}$ reduction in several combinations of air staging, fuel reburning, and flue gas-recirculation. In both studies, the simultaneous application of different types of primary methods has been proved additional $\mathrm{NO}_{\mathrm{x}}$ reduction.

More practical studies on primary methods for $\mathrm{NO}_{\mathrm{x}}$-emission reduction in real-scale reheating furnaces have also been conducted. Abuluwefa and Alnaas [23] measured the $\mathrm{NO}_{x}$ emissions in a billet steel reheating furnace at the Libyan Iron Steel Company. They found that the $\mathrm{NO}_{x}$ concentration in the flue gases depended on the air-to-fuel equivalence ratio $(\lambda)$ set in the oil-fuel combustion operations. Cheng et al. [24] also demonstrated that the $\mathrm{O}_{2}$ concentration in the furnace could be stably minimized for reducing the scale loss of the heated slab and the $\mathrm{NO}_{\mathrm{x}}$ emissions in the reheating furnaces of China Steel Corporation (CSC). Teng and Huang [19] reported that the $\mathrm{NO}_{x}$ emissions increased with the $\lambda$ values of the combustion in reheating furnaces, and the research was conducted at CSC in Kaohsiung, Taiwan. They concluded that the $\lambda$ value should be kept low to suppress $\mathrm{NO}_{\mathrm{x}}$ formation on the premise of totally complete combustion in the system. 
The aforementioned studies indicated that the reduction in $\mathrm{NO}_{\mathrm{x}}$ emission of reheating furnaces primarily depends on the applications of the primary method, in terms of the burner and furnace air-staged combustion with the properly controlled oxygen concentration. Studies investigating $\mathrm{NO}_{x}$-emission reduction for reheating furnaces in real, on-site furnaces are very scarce $[19,23,24]$. Furthermore, it is still necessary to perform systematic, planned research involving single-burner tests and real-scale reheating furnaces. Thus, the present study primarily focused on these specific aspects, including modifications to the combustion atmosphere near the burner, with different secondary combustion air (SCA), and the $\lambda$ values were modified for individual combustion zones in the reheating furnace. The NO-emission reduction performance before and after combustion modification was evaluated for a real-scale reheating furnace using effectively controlled $\lambda$ values at Incheon works of Hyundai Steel Company (HSC).

\section{Materials and Methods}

\subsection{Single-Burner Combustion Tests}

Single-burner combustion experiments were conducted using a $3 \mathrm{MW}_{\text {th }}$ gas-fired furnace at the energy experimental test building of Dangjin works of HSC, as shown in Figure 1. The design and operation of the furnace have been described in a previous report on fuel-pulsed oscillating combustion [25]. The effective dimensions of the combustion chamber, which was lined with a $0.3 \mathrm{~m}$-thick ceramic block, were $7 \mathrm{~m}$ (length $\times 1.8 \mathrm{~m}$ (width) $\times 1.8 \mathrm{~m}$ (height). The ignited flame was observed through six pairs of diametrically opposed $0.15 \mathrm{~m}$ round ports. The furnace top-wall temperature was measured using R-type thermocouples. The axial distances of the probes from the burner port were $0.7\left(Z_{1}\right)$, $1.15\left(Z_{2}\right), 2.05\left(Z_{3}\right), 2.5\left(Z_{4}\right), 2.95\left(Z_{5}\right), 3.4\left(Z_{6}\right)$, and $3.85 \mathrm{~m}\left(Z_{7}\right)$. The combustion products were exhausted from the furnace through a $0.7 \mathrm{~m}$-diameter pipe bent at $90^{\circ}$, which was vented to the stack. For the combustion experiments, an air-staged low-NOx burner designed for firing a mixed gas such as COG was used. For the burner nozzle shown in Figure 1, the fuel and air were supplied separately. The primary combustion air (PCA) entered the chamber through an axial swirler with a vane angle of $25^{\circ}$, and SCA was supplied by six distributed holes.

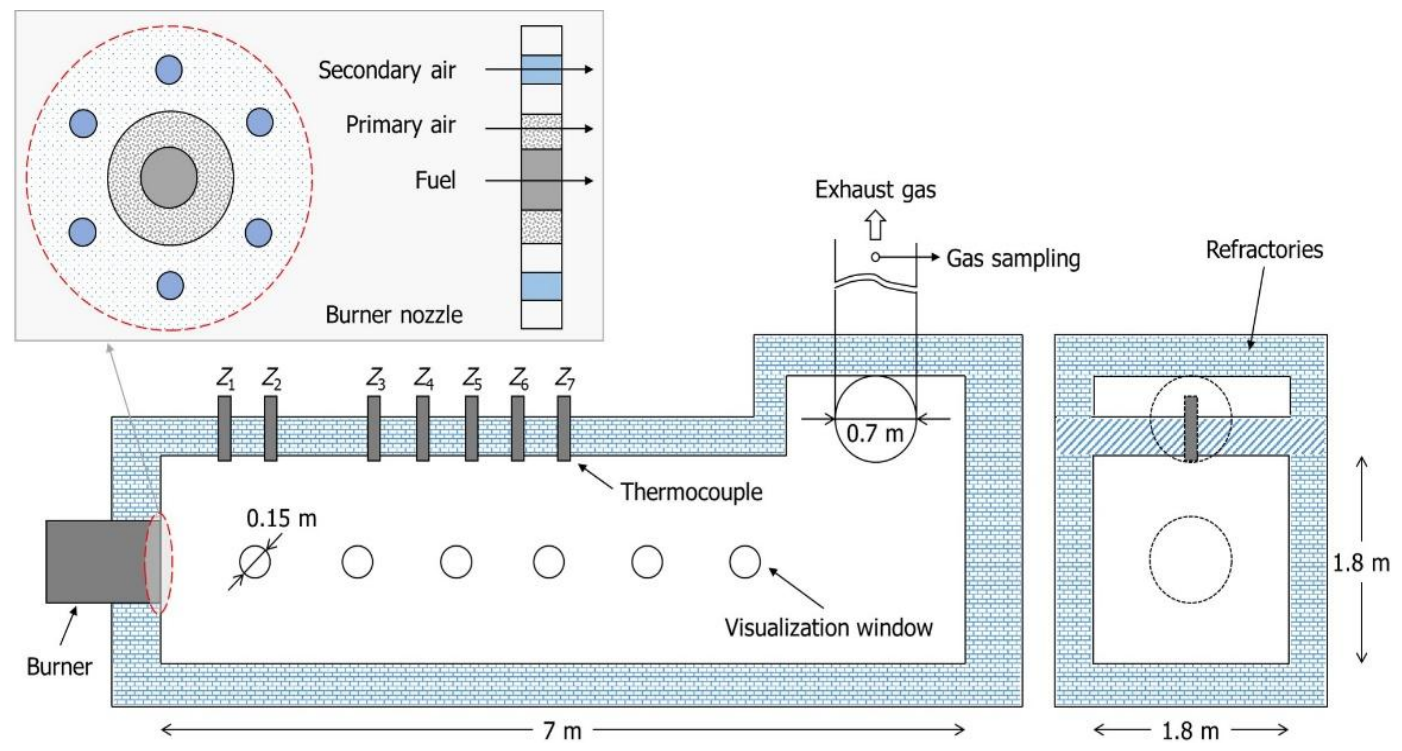

Figure 1. Schematic of the 3-MWth gas-fired furnace used for single-burner combustion tests.

As a fuel, the COG from coke oven batteries in the Dangjin works of HSC was used. The COG was composed of $57.48 \mathrm{vol} \% \mathrm{H}_{2}, 23.27 \mathrm{vol} \% \mathrm{CH}_{4}, 7.48 \mathrm{vol} \% \mathrm{~N}_{2}, 6.39 \mathrm{vol} \% \mathrm{CO}$, $3.4 \mathrm{vol} \% \mathrm{C}_{2} \mathrm{H}_{4}, 1.75 \mathrm{vol} \% \mathrm{CO}_{2}$, and $0.23 \mathrm{vol} \% \mathrm{O}_{2}$, as shown in Table 1 . The net calorific value (NCV) of the COG was $17.37 \mathrm{MJ} / \mathrm{Nm}^{3}$, and the stoichiometric air-to-fuel ratio was 
4.2. For studying the effect of the SCA ratio on the NO reduction, three test cases were considered. Cases A1-A3 represent 20\%, 40\%, and 90\% SCA and 80\%, 60\%, and 10\% PCA, respectively. In test cases A1-A3, the thermal input based on the NCV was $0.87 \mathrm{MW}_{\mathrm{th}}$, with a COG fuel flow rate of $180 \mathrm{Nm}^{3} / \mathrm{h}$. The variation in the thermal input was $\sim 0.03 \mathrm{MW}_{\text {th }}$ and the corresponding error was $\sim 3 \%$. Even though the amount of SCA was changed according to the variation of cases A1-A3, the total amount of combustion air without preheating was kept the same for all the cases. The combustion experiments involving SCA variations were controlled by regulating the $\mathrm{O}_{2}$ concentration to $\sim 4.1 \%$, which was measured at the furnace exit. For investigating the effect of the $\mathrm{O}_{2}$ concentration on the NO emission, the SCA ratio was kept constant at 20\% (case A1) while the $\mathrm{O}_{2}$ concentration at the furnace exit was controlled in the range of $0.25-4.1 \%$. The error of the $\mathrm{O}_{2}$ concentration maintained at the furnace exit was $\sim 9.8 \%$.

Table 1. Fuel composition of the COG and operating conditions for the single-burner combustion tests.

\begin{tabular}{|c|c|c|c|}
\hline \multicolumn{2}{|c|}{ Fuel Composition (Vol\%) } & \multicolumn{2}{|c|}{ COG } \\
\hline \multicolumn{2}{|c|}{$\mathrm{H}_{2}$} & \multicolumn{2}{|c|}{57.48} \\
\hline \multicolumn{2}{|c|}{$\mathrm{CH}_{4}$} & \multicolumn{2}{|c|}{23.27} \\
\hline \multicolumn{2}{|c|}{$\mathrm{N}_{2}$} & \multicolumn{2}{|c|}{7.48} \\
\hline \multicolumn{2}{|c|}{$\mathrm{CO}$} & \multicolumn{2}{|c|}{6.39} \\
\hline \multicolumn{2}{|c|}{$\mathrm{C}_{2} \mathrm{H}_{4}$} & \multicolumn{2}{|c|}{3.4} \\
\hline \multicolumn{2}{|c|}{$\mathrm{CH}_{2}$} & \multicolumn{2}{|c|}{1.75} \\
\hline \multicolumn{2}{|c|}{$\mathrm{O}_{2}$} & \multicolumn{2}{|c|}{0.23} \\
\hline \multirow{2}{*}{\multicolumn{2}{|c|}{$\begin{array}{l}\mathrm{NCV}\left(\mathrm{MJ} / \mathrm{Nm}^{3}\right) \\
\text { Stoichiometric air-to-fuel ratio (-) }\end{array}$}} & & \\
\hline & & \multicolumn{2}{|c|}{$\begin{array}{c}17.37 \\
4.21\end{array}$} \\
\hline Operating Conditions & Case A1 & Case A2 & Case A3 \\
\hline SCA $(\%)$ & 20 & 40 & 90 \\
\hline Thermal input $\left(\mathrm{MW}_{\mathrm{th}}\right)$ & $0.87 \pm 0.02$ & $0.87 \pm 0.02$ & $0.87 \pm 0.02$ \\
\hline Controlled $\mathrm{O}_{2}(\%)$ & $0.25 \pm 0.02-4.1 \pm 0.4$ & $4.1 \pm 0.4$ & $4.1 \pm 0.4$ \\
\hline
\end{tabular}

The $\mathrm{O}_{2}, \mathrm{CO}_{2}, \mathrm{CO}$, and $\mathrm{NO}$ concentrations were measured at the furnace exit using a gas analyzer (ZKJ series, Fuji Electric, Tokyo, Japan). The $\mathrm{NO}_{2}$ concentration was also measured, however, the value was less than $3 \%$ of the $\mathrm{NO}_{\mathrm{x}}$ (sum of $\mathrm{NO}$ and $\mathrm{NO}_{2}$ ) concentration. Generally, NOx emissions from combustion are mainly in the form of $\mathrm{NO}$, and thus $\mathrm{NO}_{2}$ values were not considered in this study. The gas samples were extracted through a sampling probe with a heating-type sampling line and then fed into mist filters to separate the drain and remove dust and mist. The measurements were performed at 5-min intervals, with a sampling rate of $2 \mathrm{~Hz}$. Then, the mean values were computed. The NO emission was normalized with respect to the standard of the $\mathrm{O}_{2}$ concentration (i.e., $11 \%$ ) in gaseous fuel flames, using the following relation: $\mathrm{NO}(\mathrm{ppm}) @ 11 \% \mathrm{O}_{2}=$ measured $\mathrm{NO}(\mathrm{ppm}) \times$ $\left(21 \%-11 \% \mathrm{O}_{2}\right) /\left(21 \%\right.$ - measured $\left.\mathrm{O}_{2} \%\right)$.

\subsection{Field Tests of Reheating Furnace}

Figure 2 shows a longitudinal section of the large structural mill furnace at Incheon works of HSC and photographs of the ignited flames. The furnace, which had a nominal capacity of 200 tons $/ \mathrm{h}$, heats beam blanks and large blooms. It has six individual firing zones: top-preheat, bottom-preheat, top-heat, bottom-heat, top-soak, and bottom-soak. Materials are charged into the furnace from the charge table and gradually heated as they travel through the preheat, heat, and soak zones in sequence. In contrast, the combustion products' flows are reversed, and their concentrations are measured before they reach the heat exchanger and at the stack. There are 50 burners in total: four pairs of regenerative burners are installed in the bottom-preheat zone, and 18 side burners and 24 axial burners are installed in the bottom- and top-fired zones, respectively. The photographs in Figure 2 show the side burner flames in bottom-fired zones and the axial burner flames in top-fired 
zones. The burners are fired with NG and hot air. The preheated combustion air is $\sim 550{ }^{\circ} \mathrm{C}$. The temperature inside the furnace is $1150-1250{ }^{\circ} \mathrm{C}$.
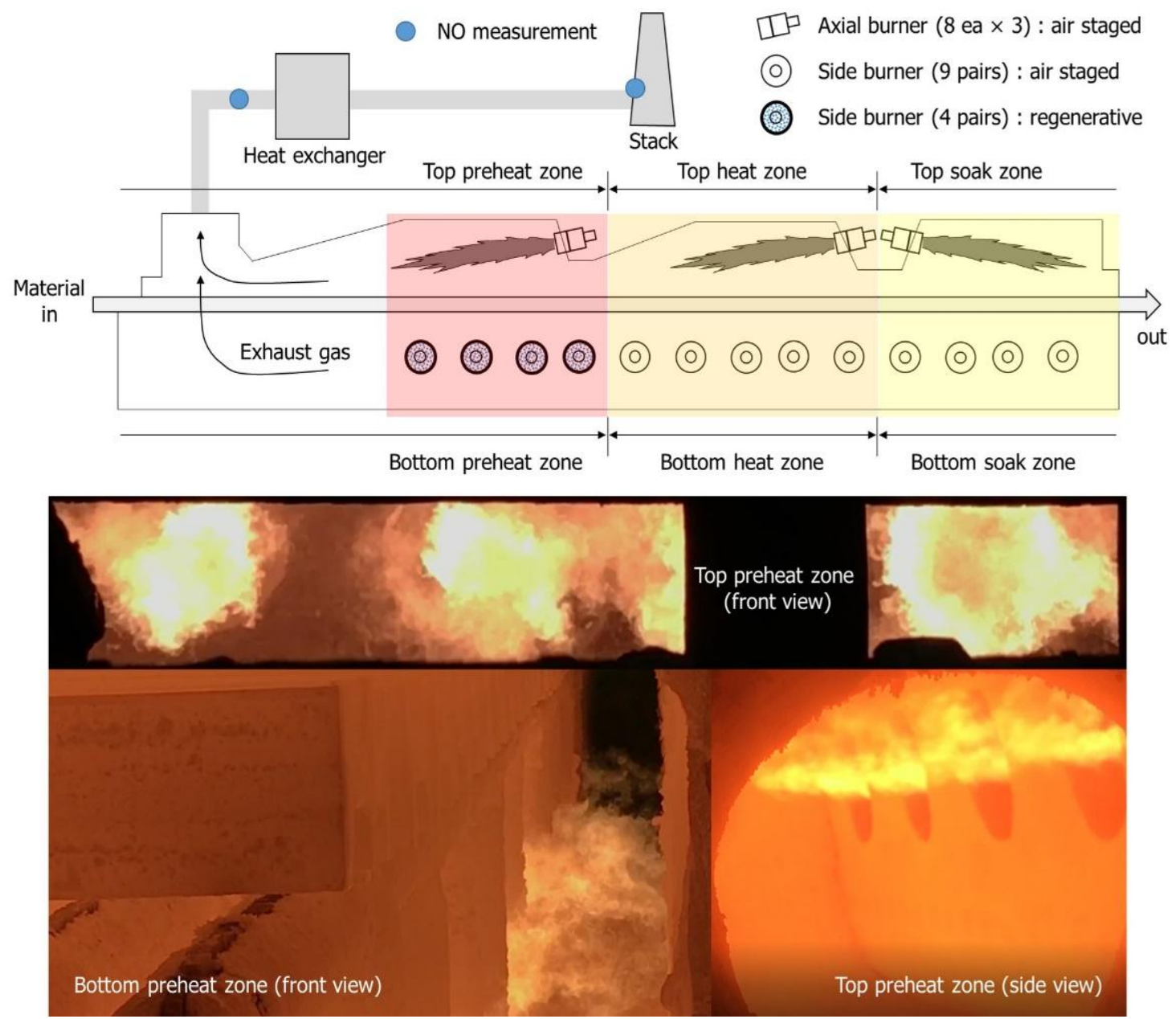

Figure 2. Schematic of the walking beam furnace at HSC's heavy structural mill and photographs of ignited flames for axial and side burners.

Commercial NG was used as the fuel, which comprised $92.88 \mathrm{vol} \% \mathrm{CH}_{4}, 5.36 \mathrm{vol} \%$ $\mathrm{C}_{2} \mathrm{H}_{6}, 1.06 \mathrm{vol} \% \mathrm{C}_{3} \mathrm{H}_{8}, 0.49 \mathrm{vol} \% \mathrm{C}_{4} \mathrm{H}_{10}$ (iso + normal), $0.19 \mathrm{vol} \% \mathrm{~N}_{2}$, and $0.02 \mathrm{vol} \%$ $\mathrm{C}_{5} \mathrm{H}_{12}$ (iso + normal), as shown in Table 2. The NCV of the NG was $38.41 \mathrm{MJ} / \mathrm{Nm}^{3}$, and the stoichiometric air-to-fuel ratio was 10.15. Case B1 was the test condition with a SCA of $30 \%$ and the air-to-fuel equivalence ratio $(\lambda)$, as shown in Table 2. Test cases B2-B4 were considered to investigate the combined effects of the SCA ratio and $\lambda$. The overall $\lambda$ values, which ranged from 1.02 to 0.95 , decreased for cases B2-B4, while the SCA ratio was maintained at $70 \%$. If the SCA ratio exceeds $70 \%$, the flame length will be long enough to directly touch the materials. Therefore, we fixed the SCA ratio at 70\% because the increased flame length will directly influence the temperature homogeneity of the materials. During these field tests, the thermal input based on the NCV ranged from 50 to $60 \mathrm{MW}_{\text {th }}$. 
Table 2. Fuel composition of commercial NG and field test conditions.

\begin{tabular}{|c|c|c|c|c|}
\hline \multicolumn{3}{|c|}{ Fuel Composition (Vol\%) } & \multicolumn{2}{|c|}{ NG } \\
\hline \multicolumn{3}{|c|}{$\mathrm{CH}_{4}$} & \multicolumn{2}{|c|}{92.88} \\
\hline \multicolumn{3}{|c|}{$\mathrm{C}_{2} \mathrm{H}_{6}$} & \multicolumn{2}{|c|}{5.36} \\
\hline \multicolumn{3}{|c|}{$\mathrm{C}_{3} \mathrm{H}_{8}$} & \multicolumn{2}{|c|}{1.06} \\
\hline \multicolumn{3}{|c|}{$\mathrm{C}_{4} \mathrm{H}_{10}$} & \multicolumn{2}{|c|}{0.49} \\
\hline \multicolumn{3}{|c|}{$\mathrm{N}_{2}$} & \multicolumn{2}{|c|}{0.19} \\
\hline \multicolumn{3}{|c|}{$\mathrm{C}_{5} \mathrm{H}_{12}$} & \multicolumn{2}{|c|}{0.02} \\
\hline \multirow{2}{*}{\multicolumn{3}{|c|}{$\begin{array}{c}\mathrm{NCV}\left(\mathrm{MJ} / \mathrm{Nm}^{3}\right) \\
\text { Stoichiometric air-to-fuel ratio (-) }\end{array}$}} & \multirow{2}{*}{\multicolumn{2}{|c|}{$\begin{array}{l}38.41 \\
10.15\end{array}$}} \\
\hline & & & & \\
\hline Test Cases & Case B1 & Case B2 & Case B3 & Case B4 \\
\hline SCA $(\%)$ & 30 & 70 & 70 & 70 \\
\hline $\begin{array}{l}\text { Total Thermal input } \\
\left(\mathrm{MW}_{\mathrm{th}}\right)\end{array}$ & 59.67 & 56.98 & 51.82 & 49.71 \\
\hline \multicolumn{5}{|c|}{ Air-to-fuel equivalence ratio $(\lambda)(-)$, zone's thermal input ratio $(\%)$} \\
\hline Top-preheat zone & $1.04,16.09$ & $1.1,13.82$ & $1.1,17.05$ & $1.1,17.34$ \\
\hline Bottom-preheat zone & $0.95,12.98$ & $1,10.46$ & $1,14.78$ & $1,18.67$ \\
\hline Top-heat zone & $1.03,22.73$ & $1,24.86$ & $0.95,19.79$ & $0.9,20.09$ \\
\hline Bottom-heat zone & $1.03,23.47$ & $1,25.93$ & $0.95,23.45$ & $0.9,22.34$ \\
\hline Top-soak zone & $1.03,10.9$ & $1,11.69$ & $0.95,10.28$ & $0.9,8.79$ \\
\hline Bottom-soak zone & $1.03,13.83$ & $1,13.24$ & $0.95,13.24$ & $0.9,12.77$ \\
\hline Overall $(\lambda)$ & 1.02 & 1.02 & 0.98 & 0.95 \\
\hline
\end{tabular}

The concentrations of $\mathrm{O}_{2}, \mathrm{CO}_{2}, \mathrm{CO}$, and $\mathrm{NO}$ were measured before the gas reached the heat exchanger and at the stack using a flue-gas analyzer (Testo 350 series, Testo SE \& Co. KGaA, Titisee-Neustadt, Germany), as shown in Figure 2. The gas samples passed through two silica-gel driers. The measurement error associated with the Testo 350 was $\pm 0.8 \%$ for the $\mathrm{O}_{2}$ concentration throughout the measurement range $(0-25 \%), \pm 5 \mathrm{ppm}$ for the $\mathrm{NO}$ concentration in the range of $0-99 \mathrm{ppm}$, and $\pm 5 \%$ for the NO concentration in the range of 100-1999 ppm.

\section{Results and Discussion}

3.1. Effects of Operating Conditions such as $\mathrm{O}_{2}$ Concentration in Flue Gas and SCA on NO-Emission Reduction in Single-Burner Combustion

Figure 3 shows the sample time traces of the COG flow rate, furnace temperature measured at $Z_{4}$ (see Figure 1), and species concentrations of $\mathrm{O}_{2}$ and $\mathrm{NO}$ at the furnace exit for test case A1 in Table 1. During the combustion test of case A1, the SCA ratio, COG flow rate with the thermal input, and $\mathrm{O}_{2}$ concentration were maintained at $20 \%, 180 \mathrm{Nm}^{3} / \mathrm{h}$ with $0.87 \mathrm{MW}_{\text {th }}$ (without combustion air preheating), and $4 \%$, respectively. Because there were no heat sinks in the furnace, e.g., a water-cooling system or inserted steel materials, it was difficult to maintain the furnace temperature; thus, the single-burner combustion test was limited to $\sim 1200{ }^{\circ} \mathrm{C}$ at $Z_{4}$. As shown in Figure 1, the furnace top-wall temperatures measured at $Z_{1}-Z_{7}$, increased over time, and the maximum value was approximately $1150{ }^{\circ} \mathrm{C}$ at $Z_{4}$ after $160 \mathrm{~min}$. The $\mathrm{NO}$ concentration increased with the furnace temperature, because the NO generation in combustion is mainly based on thermal mechanisms [26]. Another main contributor to the NO generation in COG flames is the fuel-NO generation mechanisms [27]. Therefore, the maximum $\mathrm{NO}$ concentration was $72 \mathrm{ppm}$ at the furnace temperature of $1150{ }^{\circ} \mathrm{C}$. For a similar thermal input $\left(0.87 \mathrm{MW}_{\text {th }}\right)$, furnace temperature $\left(1150{ }^{\circ} \mathrm{C}\right)$, and $\mathrm{O}_{2}$ concentration $(4 \%)$ at the furnace exit, the value obtained for the COG fired flame (72 ppm) was approximately twice that for an NG fired flame (37 ppm) reported by Jang et al. [25]. 


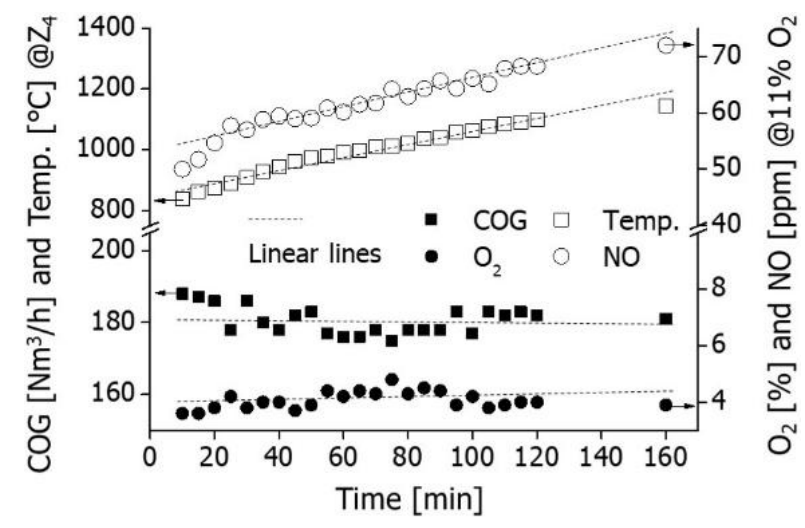

Figure 3. Measured data (fuel, temperature, $\mathrm{O}_{2}$, and $\mathrm{NO}$ ) with respect to time for the conditions of $20 \%$ SCA, $0.87 \mathrm{MW}_{\text {th }}$, and $4 \% \mathrm{O}_{2}$ at the furnace exit.

The effects of the furnace operating conditions, such as the furnace temperature at $\mathrm{Z}_{4}$ and excess $\mathrm{O}_{2}$ concentration at the furnace exit, on the $\mathrm{NO}$ emission are presented in Figure 4 for flames with a thermal input of $0.87 \mathrm{MW}_{\text {th }}$ and an SCA ratio of $20 \%$. The NO emission obtained at $4 \% \mathrm{O}_{2}$ concentration in the flue gases increased linearly as the furnace temperature increased from 874 to $1144{ }^{\circ} \mathrm{C}$, as shown in Figure $4 \mathrm{a}$. In the study of Hagihara et al. [28] involving oxygen-enriched methane flames, similar $\mathrm{NO}_{x}$ emission behavior was observed, with a linear relationship between the temperature and $\mathrm{NO}_{\mathrm{x}}$ emission in the furnace-temperature range of $1050-1450{ }^{\circ} \mathrm{C}$. This is supported by a theoretical calculation result [22] which showed that the $\mathrm{NO}$ emission from the combustion at $1327^{\circ} \mathrm{C}$ increases almost 6 times that at $1077^{\circ} \mathrm{C}$.
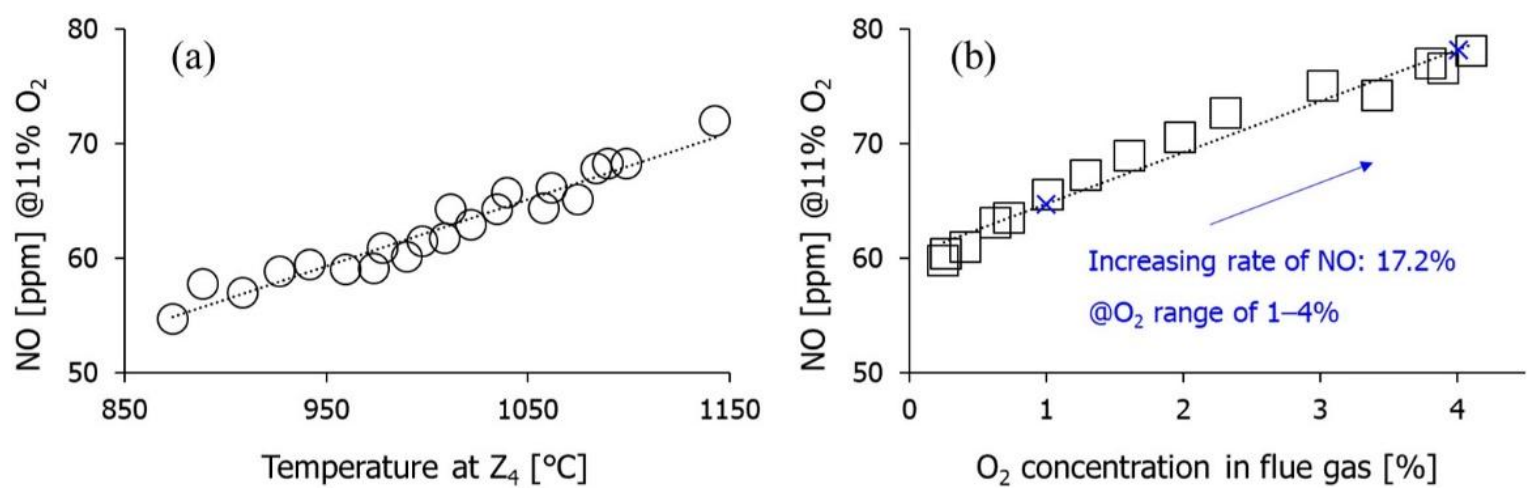

Figure 4. Effects of the temperature and oxygen concentration of exhaust gases on the NO emission under the conditions of $20 \%$ SCA and $0.87 \mathrm{MW}_{\mathrm{th}}$ : (a) temperature and (b) $\mathrm{O}_{2}$ concentration.

As shown in Figure $4 b$, the $\mathrm{NO}$ emission depended on the excess $\mathrm{O}_{2}$ concentration in the flue gas. When the $\mathrm{O}_{2}$ concentration in the flue gas ranged from $0.25 \%$ to $4.11 \%$, the $\mathrm{NO}$ concentration linearly increased from 60 to $78 \mathrm{ppm}$ at the corresponding furnace temperature ranging from 1207 to $1153{ }^{\circ} \mathrm{C}$ in $Z_{4}$. The increasing rate of $\mathrm{NO}$ emission in the $\mathrm{O}_{2}$-concentration range of $1-4 \%$ was $17.2 \%$. This result is similar that obtained by Malfa et al. [29], who observed an increasing rate of $19.4 \%$ in COG firing with an air preheated temperature of $450{ }^{\circ} \mathrm{C}$. In the study of Charon et al. [15] on oxy-NG flames, the tendency of the $\mathrm{NO}_{\mathrm{x}}$ increment with an increasing $\mathrm{O}_{2}$ concentration in the flue gas was clear below $4 \% \mathrm{O}_{2}$, while the slope was smoother than that in the present study owing to the impact of the lower flame temperature above $4 \% \mathrm{O}_{2}$.

The concept of the air-staged combustion burner for NO-emission reduction in the present study and the corresponding flame configurations are presented in Figure 5. When using such an air-stage combustion burner, it is possible to reduce the combustion air 
flow rate supplied to the center of the burner nozzle (PCA) and increase the ratio of the combustion air flow rate outside the burner nozzle (SCA). The visual flame images (side views on the first window of Figure 1) obtained using a consumer camera (iPhone 7, Apple Inc., Cupertino, CA, USA) for the case A1 and A3 flames are shown in Figure 5a,b, respectively. For case A1, the flame was highly stabilized (attached) owing to the swirled PCA (ratio of $80 \%$ ); however, a lifted (detached) flame was observed for case A3. When the amount of PCA was reduced, incomplete combustion occurred, because of the insufficient combustion air in the primary combustion zone (PCZ), and the unburned fuel in this zone flowed away from the burner in the form of combustion intermediates. In this process, the flame temperature in the $\mathrm{PCZ}$ was reduced, and the production of NO was suppressed. Then, the unburned fuel reacted and was burned completely with SCA supplied from the outside of the burner nozzle. Thus, the observed flame in Figure $5 \mathrm{~b}$ is longer than that in Figure 5a.
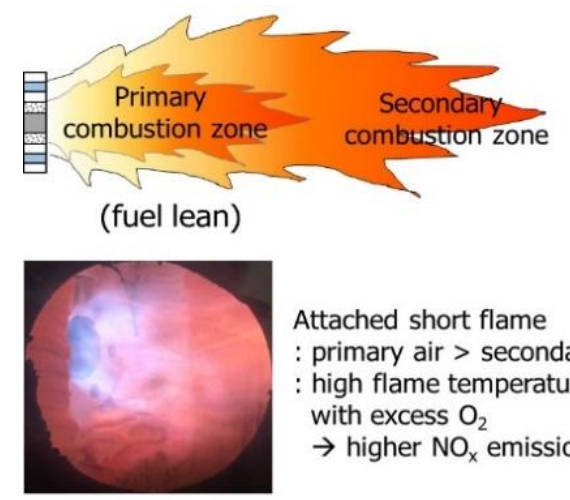

Attached short flame : primary air > secondary air : high flame temperature with excess $\mathrm{O}_{2}$ $\rightarrow$ higher $\mathrm{NO}_{x}$ emission

(a) Case A1
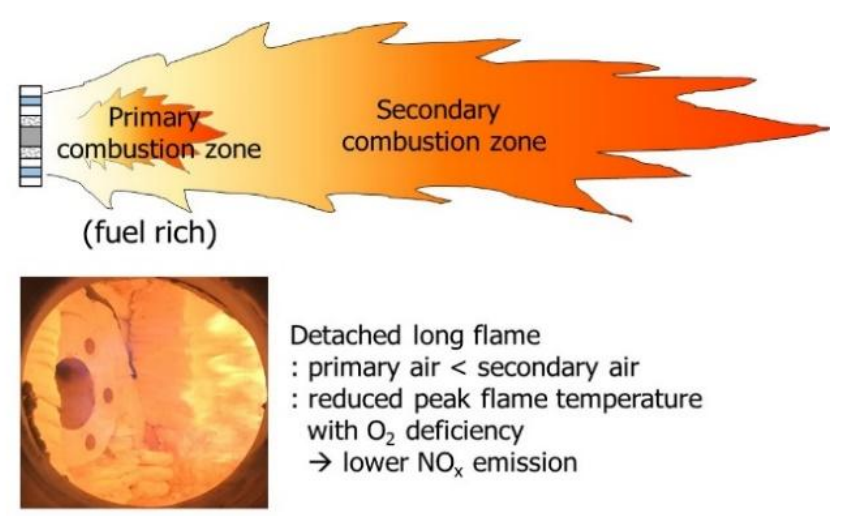

Detached long flame

: primary air < secondary air

: reduced peak flame temperature

with $\mathrm{O}_{2}$ deficiency

$\rightarrow$ lower $\mathrm{NO}_{\mathrm{x}}$ emission

(b) Case A3

Figure 5. Flame configurations with the air-staged burner concept for NO emission reduction and visualized flame photographs: (a) case A1 (20\% SCA) and (b) case A3 (90\% SCA).

Regarding the above NO reduction concept using burner air staging, the effects of the SCA ratio on the NO emission at the furnace exit and the temperature distribution of the furnace top-wall are presented Figure 6. The results of test cases A1-A3 were obtained after 130 min of firing with an $\mathrm{O}_{2}$ concentration of $4 \%$ in the flue gas. In all the test cases, the temperature increased and decreased over the length of the furnace, and the cross point was observed at a burner nozzle distance of approximately $2.3 \mathrm{~m}$. In the PCZ before the cross point, the temperature increased with the decreasing SCA ratio; conversely, it decreased in the secondary combustion zone after the cross point. The $\mathrm{NO}$ emission decreased as the SCA ratio increased. In particular, when the SCA ratio increased from $20 \%$ to $90 \%$, the level of $\mathrm{NO}$ emissions decreased from 69.43 to $43.52 \mathrm{ppm}$, and the reduction rate was $37.3 \%$. Jing et al. [30] and Li and Miao [31] obtained qualitatively similar results even though their studies were conducted using pulverized coal-fired boilers. Near the burner, the $\mathrm{NO}_{x}$ concentration decreased and the gas temperature increased, with a decreasing PCA ratio [30]. As the SCA ratio increased from $47 \%$ to $65 \%$, the $\mathrm{NO}$ emission at the furnace exit decreased monotonously from 294 to $210 \mathrm{ppm}$ [31]. 


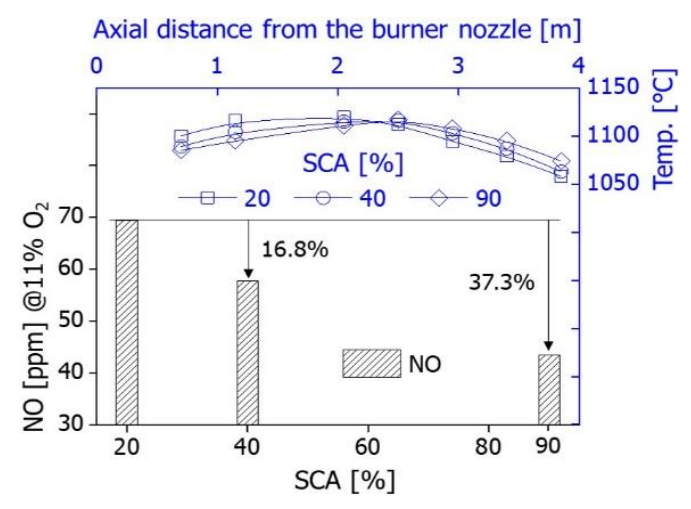

Figure 6. Effects of the SCA (test cases A1-A3) on the NO emission reduction and temperature distribution, obtained at firing after $130 \mathrm{~min}$ with an $\mathrm{O}_{2}$ concentration of $4 \%$ in the flue gas.

3.2. NO-Emission Reduction Performance with Combustion-Zone Control of Air-to-Fuel Equivalence Ratios in Reheating Furnace

Figure 7 shows the combustion modification concept of the reheating furnace at Incheon works of HSC based on the air-staged combustion with control of the air-to-fuel equivalence ratios of individual combustion zones. The furnace air-staged combustion intentionally unbalances the $\lambda$ values in each combustion zone, thereby generating incomplete combustion in high-temperature combustion zones of the furnace, such as heating and soaking zones, and supplying excess air $(\lambda>1.0)$ in the low-temperature combustion zone (preheat) to induce complete combustion. This is similar to the burner air-staged combustion, as shown in Figure 5, in that the combustion reaction is delayed according to the oxygen concentration control and the thermal $\mathrm{NO}_{\mathrm{x}}$ generation is reduced as a result. However, in contrast to burner air-staged combustion, in furnace air-staged combustion, the entire furnace is used as a reactor. Furnace air-staged combustion, which is similar to the concept investigated in the present study, was described in reports on $\mathrm{NO}_{\mathrm{x}}$ emission and scale reduction by Jaafar [16], Sung et al. [32,33], Schwotzer et al. [34], and Thekdi [35].

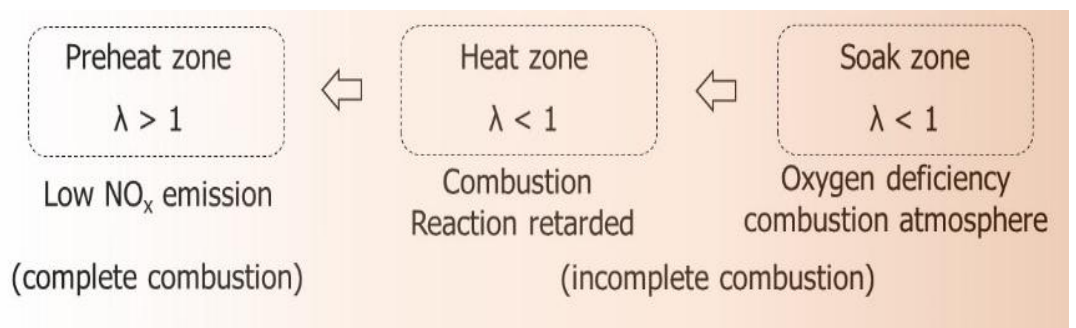

Figure 7. Concept of $\mathrm{NO}$ emission reduction for the reheating furnace using a staged combustion furnace with air-to-fuel ratio control of individual combustion zones.

The effects of the SCA ratio and $\lambda$ on the NO emissions in the reheating furnace were tested, as shown in Figures 8 and 9. Figure 8 shows the NO emissions obtained before gas the gas reached heat exchanger (2-s instantaneous values) and stack (5-min mean values) during modification of the SCA for test case B1 in Table 2. Clearly, the NO emission decreased with the increasing SCA ratio at both measurement locations, even though the values fluctuated during the test. The mean values of the $\mathrm{NO}$ emissions for short flames (SCA of 30\%) and long flames (SCA of 70\%) were 106 and 95 ppm, respectively. The reduction of the $\mathrm{NO}$ emission was $10.3 \%$ based on the value at the stack. For the test case with an SCA ratio of $70 \%$, the NO emission formed in the PCZ was close to the minimum value for the entire combustion zone; the amount of $\mathrm{NO}$ emission at this location depends on the available $\mathrm{O}_{2}$ concentration [27]. These results are qualitatively consistent with the results of the single-burner combustion tests in Figure 6 and the combustion modification study of Teng [21]. 


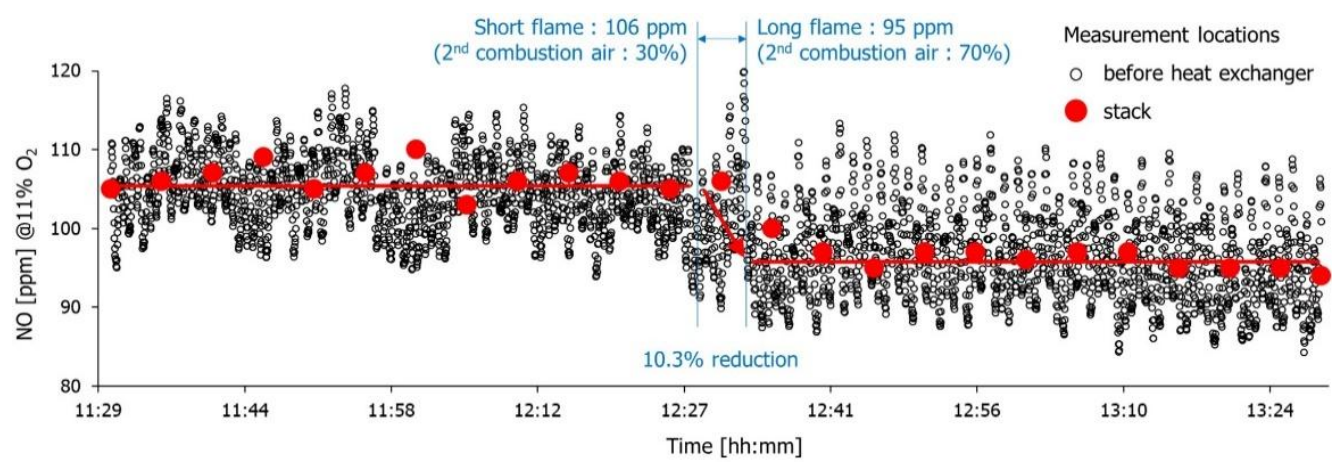

Figure 8. NO emission reduction achieved by increasing the SCA ratio from 30\% (before: short flame) to $70 \%$ (after: long flame); the $\lambda$ values for the top-preheat, bottom-preheat, and four zones (heat and soak) are 1.04, 0.95 , and 1.03, respectively.

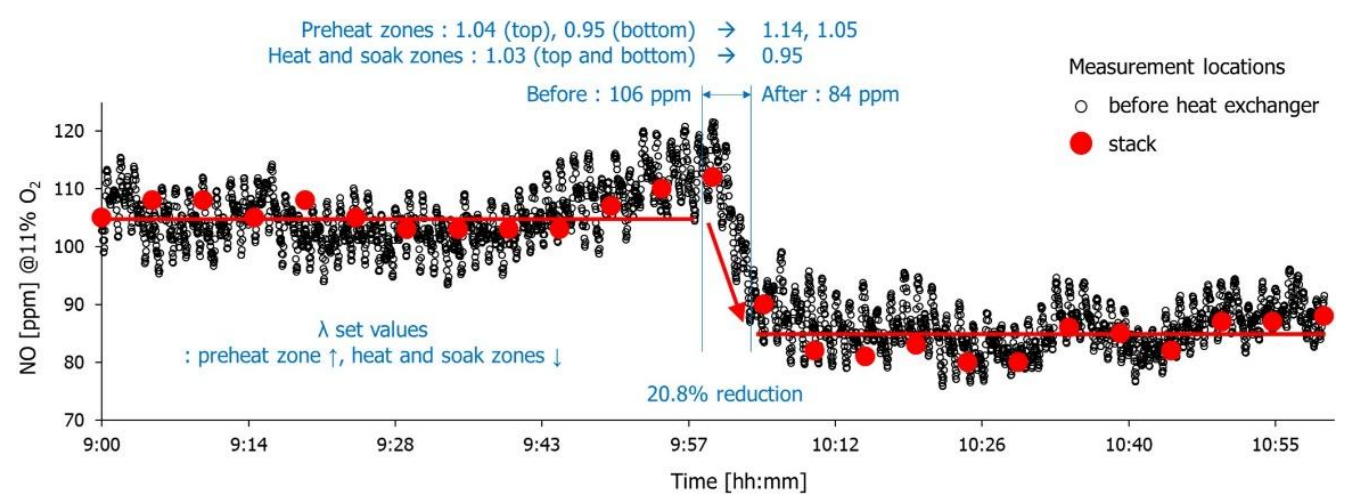

Figure 9. NO emission reduction achieved by controlling air-to-fuel equivalence ratios of individual combustion zones at a fixed SCA ratio of $30 \%$; the $\lambda$ values for the top-preheat, bottom-preheat, and four zones (heat and soak) were fixed at 1.14 , 1.05 , and 0.95 , respectively.

To investigate the effect of the $\lambda$ control for individual combustion zones on the NO emission, the SCA was fixed at $30 \%$. Figure 9 shows the NO emission obtained at two different measurement locations (before the heat exchanger and stack). During the test, the set values of $\lambda$ in the top-preheat, bottom-preheat, and four zones (heat and soak) were changed from 1.04, 0.95, and 1.03 to 1.14, 1.05, and 0.95, respectively. As shown in Figure 9, the NO emission level was significantly reduced after the modification, although the overall $\lambda$ values before and after the modifications were similar (1.02 and 1.0, respectively). The value was $106 \mathrm{ppm}$ before the modifications and $84 \mathrm{ppm}$ after the modifications, and the corresponding NO-emission reduction was $20.8 \%$. At this point, the $\mathrm{O}_{2}$ concentration measured in the stack was $6.48 \%$ and 6.41 when the overall $\lambda$ value was 1.02 and 1.0, respectively. Interestingly, although both tests operated under stoichiometric conditions for the combustion air and fuel supplied to the burner, the $\mathrm{O}_{2}$ concentration measured in the stack was rather high. This can be explained by the infiltrated air from outside into the furnace through the doors when they are opened for heated materials charge and discharge. The $\mathrm{O}_{2}$ concentration in the stack increased with the decrease in furnace loads (fuel flow rates) and the similar discussion with outside air infiltrations was reported in refs. $[19,24]$. The thermal input ratio (heat and soak zones/entire zones) was approximately $70 \%$ both before and after the modifications. In the combustion zones of heat and soak, the $\lambda$ value was lower with $\mathrm{O}_{2}$-deficient atmospheres after modification than the value before modification, as shown in Figure 7. Therefore, the level of NO emissions was reduced after the modifications. Teng and Huang [19] obtained similar results. They reported that the $\mathrm{NO}_{x}$ emission level was reduced with a decrease in the $\lambda$ values in the ranges of $0.8-1.05$ for the heat zone and $0.8-1.25$ for the soak zone, and the $\lambda$ for the soak zone had a greater effect on the $\mathrm{NO}_{\mathrm{x}}$ reduction than that for the heat zone. 
Figure 10 shows the combined effects of the overall $\lambda$ values in the furnace and the SCA ratios on the NO-emission reduction in the overall thermal-input range of 49.71-59.67 $\mathrm{MW}_{\text {th }}$ with slightly different thermal inputs for individual combustion zones. The overall $\lambda$ value of case B1 for $30 \%$ SCA was 1.02 with different individual $\lambda$ values (top-preheat: 1.04; bottom-preheat: 0.95; others: 1.03). In cases B2-B4, as shown in Table 2, the overall $\lambda$ values decreased (ranging from 1.02 to 0.95 ) at a fixed SCA ratio of $70 \%$, and the $\lambda$ values of the heat and soak zones also decreased, ranging from 1.0 to 0.9 at fixed $\lambda$ values of 1.1 for the top-preheat zone and 1.0 for the bottom-preheat zone. As shown in Figure 10, the NO emission decreased with a reduction in the overall $\lambda$ at a fixed SCA ratio of 70\%. The NO emissions for cases B1, B2, B3, and B4 were 111, 96, 79, and 70 ppm, respectively. The reduction in NO emission for case B2 compared with case B1 was $13.5 \%$. The reduction increased for cases B3 and B4, and the maximum reduction was $36.9 \%$ for case B4, with an overall $\lambda$ of 0.95 and different individual $\lambda$ values (top-preheat: 1.1; bottom-preheat: 1.0; others: 0.9 ). However, the CO emission levels for cases B3 and B4 were hundreds of ppm, because the overall $\lambda$ value was $<1$ and incomplete combustion occurred in both test cases. According to the study of Jaafar [16], the CO emission level increases as $\lambda$ decreases for air-staged combustion. In the present firing tests, quantitative data regarding the $\mathrm{CO}$ emission were not obtained. Because the incomplete combustion operation of the reheating furnace at HSC is a violation of the operation instructions, we simply checked whether any CO emission occurred. Thus, it was important to optimize the $\lambda$ values for the combustion zones of the furnace without the problem of incomplete combustion (overall $\lambda>1.0$ ), as shown in Figure 11.

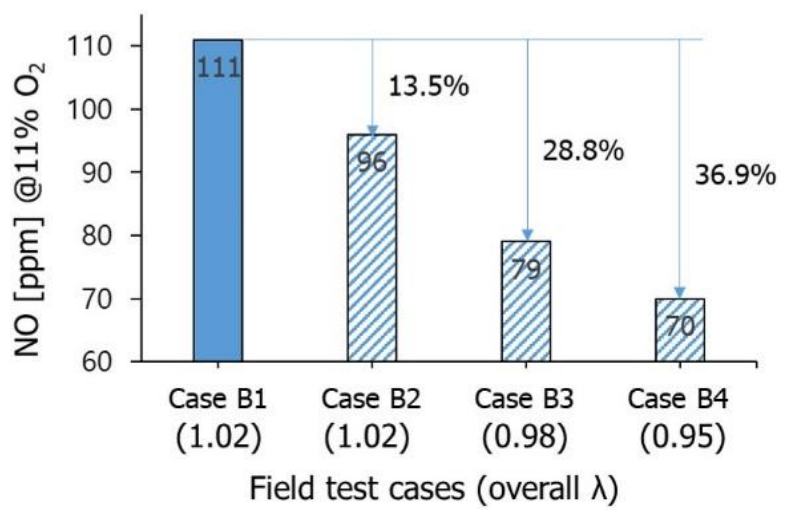

Figure 10. Combined effects of the overall $\lambda$ value and SCA ratio on the NO-emission reduction for different field test cases.

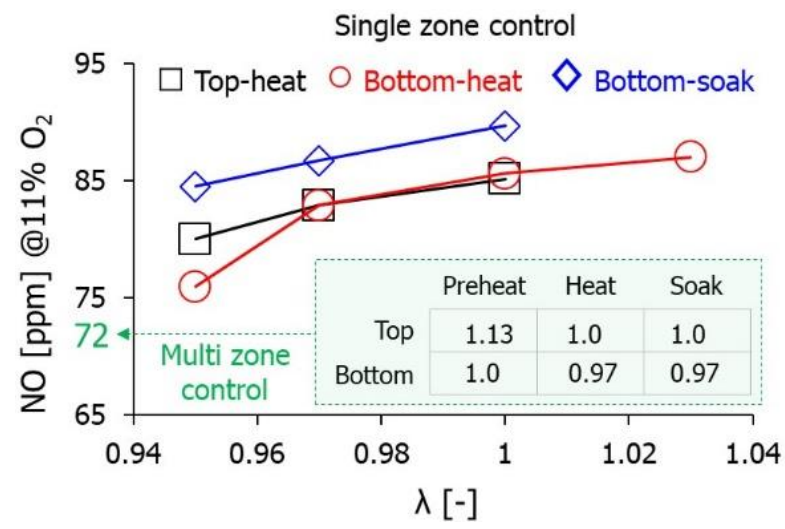

Figure 11. Comparison between singe- and multi-zone control of $\lambda$ with regard to the NO emission at the overall $\lambda$ and a SCA ratio of $30 \%$. 
To investigate the effects of single- and multi-zone control of $\lambda$ on NO emissions, the overall $\lambda$ and SCA ratio were maintained at 1.02 (complete combustion atmosphere) and $30 \%$, without CO emissions. The individual $\lambda$ values were also fixed (top-preheat: 1.1 ; bottom-preheat: 1.0; top-heat: 1.0; bottom-heat: 1.03; top-soak: 1.0; bottom-soak: 1.0). The firing tests were performed at decreasing $\lambda$ values (from 1.03 to 0.95 ) in the order of the top-heat, bottom-heat, and bottom-soak zones. Because the thermal input ratio in the top-soak zone was approximately $10 \%$ (the lowest value among all the combustion zones), this zone was not considered in the tests. As shown in Figure 11, in all three cases, the NO emission level decreased linearly with a reduction in $\lambda$. The thermal input ratios for the top-heat, bottom-heat, and bottom-soak regions were $22 \%, 24 \%$, and $14 \%$, respectively. Thus, the effect of $\lambda$ control on the NO emission was larger for the heat zones than for the soak zone. To ensure complete combustion of the fuel in the furnace, the $\lambda$ values of the downstream combustion zones (preheat) were controlled with $\lambda>1.0$, as shown in Figure 7. Conversely, in the air-staged combustion furnace for NO-emission reduction, the $\lambda$ values in heat and soak zones whose thermal input ratio is approximately $70 \%$ should be controlled with $\lambda<1.0$ because reducing the $\lambda$ in these zones can reduce the NO emissions, as shown in Figure 11. Consequently, the multi-zone control of the $\lambda$ values yielded the lowest $\mathrm{NO}$ emission level, and the $\lambda$ values for the six individual combustion zones were set as 1.13 (top-preheat), 1.0 (bottom-preheat), 1.0 (top-heat), 0.97 (bottom-heat), 1.0 (top-soak), and 0.97 (bottom-soak), without any incomplete combustions. The performance of the $\mathrm{NO}$-emission reductions before and after the combustion modifications in the reheating furnace is summarized in Table 3. In this study, NO emission reduction of approximately $23 \%$ was achieved through the field test campaigns over approximately 6 months (January to July 2016). Because the change in the $\mathrm{O}_{2}$ atmosphere inside the reheating furnace affects the $\mathrm{NO}_{\mathrm{x}}$ emissions as well as the scale formation characteristics, further research may be needed to focus on the scale formation and reduction characteristics with variations in combustion atmospheres inside the reheating furnace. Nevertheless, this study suggests that combustion modifications can be economically applied for burner and furnace airstaged combustions in steel reheating furnaces, without additional equipment investments.

Table 3. Fuel composition of commercial NG and field test conditions.

\begin{tabular}{cccc}
\hline Item & $\begin{array}{c}\text { Before } \\
\text { Modification }\end{array}$ & $\begin{array}{c}\text { After } \\
\text { Modification 1 }\end{array}$ & $\begin{array}{c}\text { After } \\
\text { Modification 2 }\end{array}$ \\
\hline SCA (\%) & 30 & 70 & 70 \\
Total thermal input $\left(\mathrm{MW}_{\text {th }}\right)$ & 59.67 & 56.98 & 51.82 \\
Top-preheat zone & 1.04 & 1.1 & 1.13 \\
Bottom-preheat zone & 0.95 & 1.0 & 1.0 \\
Individual $\lambda \quad 1.03$ & 1.0 & 1.0 \\
$\quad$ Top-heat zone & 1.03 & 1.03 & 0.97 \\
$\quad$ Bottom-heat zone & 1.03 & 1.0 & 1.0 \\
Top-soak zone & 1.03 & 1.0 & 1.03 \\
Bottom-soak zone & 1.02 & 1.02 & 1.02 \\
NO (ppm) @11\% $\mathrm{O}_{2}$ & 110 & 97 & 85 \\
$\mathrm{NO}$ reduction $(\%)$ & - & 11.8 & 22.7 \\
\hline
\end{tabular}

\section{Conclusions}

This paper presents experimental studies on NO-emission reduction in a reheating furnace through burner and furnace air-staged combustions. Combustion tests were conducted using a single-burner combustion system and a real-scale reheating furnace at HSC. The effects of the SCA ratio and air-to-fuel equivalence ratio $(\lambda)$ on the NO emission level were evaluated. The main results are summarized below:

(1) For the single burner combustion test, the NO emission reduction performance increased with the SCA ratio, in accordance with the concept of the burner air-staged combustion. The NO-emission reduction was 37.3\% at firing with 90\% SCA, because of the reducing atmosphere generated in the PCZ. The flame at a higher SCA ratio 
was longer and was detached from the burner nozzle; thus, the temperature in the PCZ was reduced.

(2) For the field test, the NO emission was reduced at the long flame, in accordance with the single-burner experiments, and the NO emission level was reduced by $10.3 \%$ with an increase in the SCA ratio from $30 \%$ to $70 \%$. The overall $\lambda$ control significantly affected the NO-emission reduction, and the maximum reduction was $37 \%$ at an overall $\lambda$ of 0.95 with different individual $\lambda$ values (top-preheat: 1.1 ; bottom-preheat: 1.0; others: 0.9 ). However, the optimum $\lambda$ value should be adjusted with consideration of complete combustion (overall $\lambda>1.0$ ) of the fuel supplied. Thus, in the furnace air-staged combustion, the $\lambda$ values for the preheat zone and downstream combustion zone should be controlled as $\lambda>1.0$.

(3) With single-zone control of the $\lambda$ values, the NO emission decreased linearly with a reduction in the $\lambda$ values for the individual firing tests (top-heat, bottom-heat, and bottom-soak zones). Finally, the multi-zone control of $\lambda$ for the six individual combustion zones was yielded optimal values of 1.13 (top-preheat), 1.0 (bottompreheat), 1.0 (top-heat), 0.97 (bottom-heat), 1.0 (top-soak), and 0.97 (bottom-soak). Under this firing condition, the NO-emission level was reduced by approximately $23 \%$ after the modifications for burner and furnace air-staged combustions.

Author Contributions: Conceptualization, C.O.; methodology, S.C.; validation, S.P. and K.P.; investigation, S.K. and B.J.; resources, T.J.; data curation, S.K. and B.J.; writing —original draft preparation, Y.S.; writing - review and editing, Y.S.; visualization, S.P. and K.P.; supervision, T.J.; project administration, C.O. All authors have read and agreed to the published version of the manuscript.

Funding: This work was supported by the National Research Foundation of Korea (NRF) grant funded by the Korea government (MSIT) (No. 2020R1F1A1049268).

Conflicts of Interest: The authors declare no conflict of interest.

\section{Abbreviations}

CaseA Test conditions in single burner experiments with different secondary combustion air

CaseB Field test conditions with different secondary combustion air and air-to-fuel equivalence ratio

CATS Cap-and-trade system

COG Coke oven gas

CSC China Steel Corporation

HSC Hyundai steel company

LPG Liquefied petroleum gas

NCV Net calorific value

NG Natural gas

PCA Primary combustion air

PCZ Primary combustion zone

SCA Secondary combustion air

SMA Seoul metropolitan area

$\mathrm{Z} \quad$ Axial distance from the burner port $(\mathrm{m}): Z_{1}-Z_{7}(0.7-3.4 \mathrm{~m})$

$\lambda$ Air-to-fuel equivalence ratio

\section{References}

1. Chen, D.; Lu, B.; Zhang, X.; Dai, F.; Chen, G.; Liu, Y. Fluctuation Characteristics of Billet Region Gas Consumption in Reheating Furnace Based on Energy Apportionment Model. Appl. Therm. Eng. 2018, 136, 152-160. [CrossRef]

2. Lu, B.; Tang, K.; Chen, D.; Han, Y.; Wang, S.; He, X.; Chen, G. A Novel Approach for Lean Energy Operation Based on Energy Apportionment Model in Reheating Furnace. Energy 2019, 182, 1239-1249. [CrossRef]

3. Wang, X.; Lin, B. Factor and Fuel Substitution in China's Iron \& Steel Industry: Evidence and Policy Implications. J. Clean. Prod. 2017, 141, 751-759.

4. Abdul-Wahab, S.; Fadlallah, S.; Al-Rashdi, M. Evaluation of the Impact of Ground-level Concentrations of $\mathrm{SO}_{2}, \mathrm{NO}_{\mathrm{x}}, \mathrm{CO}$, and $\mathrm{PM}_{10}$ Emitted from a Steel Melting Plant on Muscat, Oman. Sust. Cities Soc. 2018, 38, 675-683. [CrossRef]

5. Chakravarty, K.; Kumar, S. Increase in Energy Efficiency of a Steel Billet Reheating Furnace by Heat Balance Study and Process Improvement. Energy Rep. 2020, 6, 343-349. [CrossRef] 
6. Sun, W.; Zhou, Y.; Lv, J.; Wu, J. Assessment of Multi-air Emissions: Case of Particulate Matter (Dust), $\mathrm{SO}_{2}, \mathrm{NO}_{\mathrm{x}}$ and CO 2 from Iron and Steel Industry of China. J. Clean. Prod. 2019, 232, 350-358. [CrossRef]

7. Yi, Z.; Su, Z.; Li, G.; Yang, Q.; Zhang, W. Development of a Double Model Slab Tracking Control System for the Continuous Reheating Furnace. Int. J. Heat Mass Transf. 2017, 113, 861-874. [CrossRef]

8. García, A.M.; Colorado, A.F.; Obando, J.E.; Arrieta, C.E.; Amell, A.A. Effect of the Burner Position on an Austenitizing Process in a Walking-beam Type Reheating Furnace. Appl. Therm. Eng. 2019, 153, 633-645. [CrossRef]

9. Rosado, D.J.M.; Chávez, S.B.R.; Gutierrez, J.A.; de Araújo, F.H.M.; de Carvalho, J.A., Jr.; Mendiburu, A.Z. Energetic Analysis of Reheating Furnaces in the Combustion of Coke Oven Gas, Linz-Donawitz Gas and Blast Furnace Gas in the Steel Industry. Appl. Therm. Eng. 2020, 169, 114905. [CrossRef]

10. He, K.; Wang, L. A Review of Energy Use and Energy-efficient Technologies for the Iron and Steel Industry. Renew. Sustain. Energy Rev. 2017, 70, 1022-1039. [CrossRef]

11. Yeo, M.J.; Kim, Y.P. Flexible Operation of the Cap-and-trade System for the Air Pollutants in the Seoul Metropolitan Area. J. Environ. Manag. 2012, 105, 138-143. [CrossRef]

12. Kim, Y.P. Trend and Characteristics of Ambient Particles in Seoul. Asian J. Atmos. Environ. 2007, 1, 9-13. [CrossRef]

13. Trnka, D. Policies, Regulatory Framework and Enforcement for Air Quality Management: The Case of Korea; OECD: Paris, France, 2020. Available online: http://www.oecd.org/officialdocuments/publicdisplaydocumentpdf/?cote=ENV/WKP(2020)5 \&docLanguage $=$ En (accessed on 6 March 2021).

14. Ministry of Environment. Republic of Korea. 2015. Available online: http://eng.me.go.kr/eng/file/readDownloadFile.do? fileId $=115224 \&$ fileSeq $=1 \&$ open $Y n=Y$ (accessed on 6 March 2021).

15. Charon, O.; Jouvaud, D.; Genies, B. Pulsated $\mathrm{O}_{2}$ /fuel Flame as a New Technique for Low $\mathrm{NO}_{\mathrm{x}}$ Emission. Combust. Sci. Technol. 1993, 93, 211-222. [CrossRef]

16. Jaafar, M.N.M.; Ishak, M.S.A.; Saharin, S. Removal of $\mathrm{NO}_{\mathrm{x}}$ and $\mathrm{CO}$ from a Burner System. Environ. Sci. Technol. 2010, 44, 3111-3115. [CrossRef] [PubMed]

17. Lukáč, L.; Rimár, M.; Variny, M.; Kizek, J.; Lukáč, P.; Jablonský, G.; Janošovský, J.; Fedák, M. Experimental Investigation of Primary de- $\mathrm{NO}_{x}$ Methods Application Effects on $\mathrm{NO}_{x}$ and CO Emissions from a Small-scale Furnace. Processes 2020, 8, 940. [CrossRef]

18. Ren, S.; Wang, X. $\mathrm{NO}_{\mathrm{x}}$ Emission and Its Reduction Mechanism Investigation in One Diffusion-like Vortex-tube Combustor. J. Clean. Prod. 2020, 274, 123138. [CrossRef]

19. Teng, H.; Huang, T.S. Control of $\mathrm{NO}_{\mathrm{x}}$ Emissions Through Combustion Modifications for Reheating Furnaces in Steel Plants. Fuel 1996, 75, 149-156. [CrossRef]

20. Zajemska, M.; Musial, D.; Poskart, A. Effective Methods of Reduction of Nitrogen Oxides Concentration During the Natural Gas Combustion. Environ. Technol. 2014, 35, 602-610. [CrossRef]

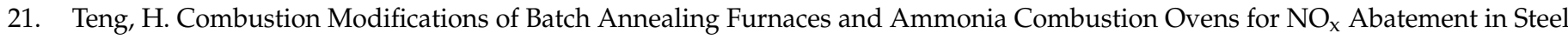
Plants. J. Air Waste Manag. Assoc. 1996, 46, 1171-1178. [CrossRef] [PubMed]

22. Cheong, K.P.; Wang, G.; Mi, J.; Wang, B.; Zhu, R.; Ren, W. Premixed MILD Combustion of Propane in a Cylindrical Furnace with a Single Het Burner: Combustion and Emissions Characteristics. Energy Fuels 2018, 32, 8817-8829. [CrossRef]

23. Abuluwefa, H.; Alnaas, A. Nitrogen and Sulfur Oxides Emissions from Fuel Oil Combustion in Industrial Steel Reheat Furnace. Int. J. Eng. Inf. Technol. 2017, 3, 71-74.

24. Cheng, H.H.; Hsu, Y.L.; Wang, C.H.; Hsia, F.Y.; Ou, T.T. Control Method for Low Oxygen Concentration in Reheating Furnace. China Steel Tech. Rep. 2011, 24, 20-27.

25. Jang, B.; Oh, C.; Ahn, S.; Kim, Y.; Park, J.; Choi, M.; Sung, Y. Nitric Oxide Emission Reduction and Thermal Characteristics of Fuel-pulsed Oscillating Combustion in an Industrial Burner System. Energy 2021, 216, 119263. [CrossRef]

26. Zeldovich, Y.B. The Oxidation of Nitrogen in Combustion Explosions. Acta Physicochim. USSR 1946, 21, 577-628.

27. Miller, J.A.; Bowman, C.T. Mechanism and Modeling Chemistry in Combustion. Prog. Energy Combust. Sci. 1989, 15, 287-338. [CrossRef]

28. Hagihara, Y.; Haneji, T.; Yamamoto, Y.; Iino, K. Ultra-low $\mathrm{NO}_{\mathrm{x}}$ Oxygen-enriched Combustion System Using Oscillation Combustion Method. Energy Procedia 2017, 120, 189-196. [CrossRef]

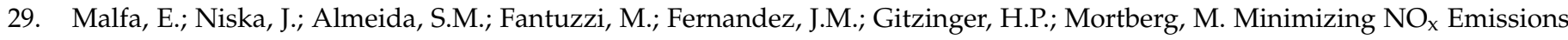
from Reheating Furnaces. In Proceedings of the 32nd Meeting on Combustion, Italian Section of the Combustion InstituteCombustion Colloquia, Napoli, Italy, 26-28 April 2009; Volume 14, pp. 1-6. Available online: http:/ / www.combustion-institute. it/proceedings/proc2009/data/V/V-14.pdf (accessed on 6 March 2021).

30. Jing, J.; Zhengqi, L.; Zhu, Q.; Chen, Z.; Ren, F. Influence of Primary Air Ratio on Flow and Combustion Characteristics and NO Emissions of a New Swirl Coal Burner. Energy 2011, 36, 1206-1213. [CrossRef]

31. Li, Z.; Miao, Z. Primary Air Ratio Affects Coal Utilization Mode and $\mathrm{NO}_{\mathrm{x}}$ Emission in Lignite Pulverized Boiler. Energy 2019, 187, 116023. [CrossRef]

32. Sung, S.; Moon, C.; Eom, S.; Choi, G.; Kim, D. Coal-particle Size Effects on NO Reduction and Burnout Characteristics with Air-staged Combustion in a Pulverized Coal-fired Furnace. Fuel 2016, 182, 558-567. [CrossRef]

33. Sung, S.; Lee, S.; Kim, C.; Jun, D.; Moon, C.; Choi, G.; Kim, D. Synergistic Effect of Co-firing Woody Biomass with Coal on NO Reduction and Burnout During Air-staged Combustion. Exp. Therm. Fluid Sci. 2016, 71, 114-125. [CrossRef] 
34. Schwotzer, C.; Schnitzler, M.; Pfeifer, H. Low Scale Reheating of Semi-finished Metal Products in Furnaces with Recuperative Burners. Appl. Therm. Eng. 2018, 128, 586-594. [CrossRef]

35. Thekdi, A.C. Development of Nest Generation Heating System for Scale Free Steel Reheating. United States. 2011. Available online: https: / / doi.org/10.2172/1004059 (accessed on 6 March 2021). 